\title{
Manajemen Pemberdayaan Masyarakat Desa Di Kabupaten Bengkalis
}

\author{
${ }^{1}$ Khairul Amri, ${ }^{2}$ Adia Ferizko \\ ${ }^{1}$ Fakultas Ilmu Sosial dan Ilmu Politik Universitas Riau, Indonesia \\ ${ }^{2}$ Fakultas Ilmu Administrasi Universitas lancang Kuning, Indonesia
}

e-mail: khairul.amri@lecturer.unri.ac.id

\begin{abstract}
Abstrak
Pokok permasalah pada masalah kemiskinan di Indonesia khususnya kabupaten Bengkalis. Kemiskinan adalah masalah klasik dan terjadi hamper di seluruh Negara di dunia. baik itu kemiskinan absolut maupun kemiskinan relatif. Masalah tentang masyarakat miskin ternyata sangat kompleks, sehingga meskipun sudah banyak program-program dalam upaya pengentasan kemiskinan, namun juga tak kunjung selesai. Tujuan penelitian ini untuk mengetahui bagaimana manajemen pemberdayaan masyarakat di kabupaten bengkalis dan pemberdayaan masyarakat desa di kabupaten Bengkalis. Metode penelitian menggunakan pedekatan kualitatif studi kepustakaan, jenis penelitian menggunakan studi literatur dengan mencari referensi teori yang relevan dengan kasus atau permasalahan yang ditemukan. Hasil penelitian ini menunjukkan bahwa manajemen pemberdayaan masyarakat di kabupaten bengkalis belum maksimal, hal ini terlihat dari lemahnya upaya pemerintah dalam upaya melinearisasi kebijakan hingga tingkat desa khususnya desa tradisional yang masih tertinggal, tentu butuh sentuhan-sentuhan khusus yang bisa di tuangkan ke dalam sebuah aturan/kebijakan. Dengan kata lain, factor administrasi dan organisasi sangat mempengaruhi keberhasilan dalam pencapaian tujuan. Pemberdayaan masyarakat desa di kabupaten bengkalis juga belum terlaksana dengan maksimal. Hal ini terlihat dari lemahnya upaya pemerintah dalam upaya menduplikasi strategi dari desa yang berhasil kepada desa-desa lainnya di kabupaten bengkalis. Dalam upaya pemberdayaan masyarakat desa di kabupaten bengkalis perlu menanamkan kesadaran kepada masyarakat yang menjadi sasaran pemberdayaan terhadap pentingnya pemberdayaan tersebut agar dalam pelaksanaan, masyarakat sasaran pemberdayaan dapat lebih partisipasif.
\end{abstract}

Keywords: Manajemen, pemberdayaan, masyarakat.desa

\begin{abstract}
The main problem in the problem of poverty in Indonesia, especially Bengkalis Regency. Poverty is a classic problem and occurs in almost all countries in the world. both absolute poverty and relative poverty. The problem of the poor turns out to be very complex, so that even though there have been many programs in poverty alleviation efforts, it has also not been finished. The purpose of this study was to find out how the management of community empowerment in Bengkulu Regency and village community empowerment in Bengkalis Regency. The research method uses a qualitative approach to literature study, this type of research uses literature studies by looking for theoretical references relevant to the case or problem found. The results of this study indicate that the management of community empowerment in Bengkulu Regency is not yet maximal, this can be seen from the weak efforts of the government in an effort to line up policies at the village level, especially traditional villages that are still lagging, naturally requiring special touches that can be poured into a rule / Policy. In other words, administrative and organizational factors greatly influence success in achieving goals. Empowerment of rural communities in the Bengkulu district has also not been carried out to the maximum. This can be seen from the weak efforts of the government in an effort to duplicate the strategy of the successful village to other villages in the Regency of Bengkulu. In an effort to empower the village community in Bengkulu Regency it is
\end{abstract}


necessary to instill awareness to the people who are the target of empowerment of the importance of empowerment so that in the implementation, the target community of empowerment can be more participatory

Kata Kunci : Management, empowerment, community. Village

\section{PENDAHULUAN}

Kemiskinan adalah masalah klasik dan terjadi hamper di seluruh Negara di dunia. baik itu kemiskinan absolut maupun kemiskinan relatif. Masalah tentang masyarakat miskin ternyata sangat kompleks, sehingga meskipun sudah banyak program-program dalam upaya pengentasan kemiskinan, namun juga tak kunjung selesai. Hal ini di karenakan dalam penyelesaiannya tidak hanya dari sisi ekonomi saja namun juga dari sisi segi sosialnya. Faktor penyebab kemiskinan sebagian besar karena faktor alamiah. Selain itu karena tidak terealisasinya pemerataan hasil pembangunan juga merupakan faktor penyebab yang tidak dapat diabaikan.

Indonesia mengalami krisis sejak pertengahan tahun 1997, hal ini berdampak buruk terhadap kesejahteraan masyarakat, akibatnya tingkat kemiskinan juga terus meningkat. Hal ini menunjukkan bahwa program pemberdayaan masyarakat sangat membutuhkan dukungan dari setiap unsur, yang paling utama adalah masyarakat, sebab dalam pemberdayaan masyarakat tidak hanya sebagai objek, melainkan subjek penting dalam hal peningkatan kualitas hidup masyarakat itu sendiri.

Amanat UU No. 6 tahun 2014 tentang Desa dengan tegas menyebutkan bahwa pembangunan kawasan perdesaan dilaksanakan dalam upaya mempercepat clan meningkatkan kualitas pelayanan, pembangunan, clan pemberdayaan masyarakat desa di kawasan perdesaan melalui pendekatan pembangunan partisipatif (Pasal 83 ayat2). Amanat tersebut semakin jelas dengan disahkannya Peraturan Pemerintah (PP) No. 43 tahun 2014 tentang Desa, dimana secara operasional implemetasinya mengacu pada Peraturan Menteri Dalam Negeri (Permendagri) Nomor 51 tahun 2007 tentang Pembangunan Kawasan Berbasis Masyarakat (PKPBM) yang telah dilaksanakan di 49 kabupaten (Ditjen PMD-PSP3 IPB, 2013).

Model pembangunan yang lebih berpihak kepada rakyat adalah hal penting demi terciptanya masa depan yang lebih humanis. Pemahaman terhadap hal itu sangat penting artinya bagaimana memilih teknik dari sisi sosial termasuk bagaimana memberdayakan masyarakat dapat dilakukan secara tepat demi tercapainya tujuan-tujuan yang lebih memprioritaskan kepentingan masyarakat.

Payne (2005) menjelaskan bahwa tujuan pemberdayaan masyarakat adalah untuk membantu masyarakat memperoleh dayauntuk mengambil keputusan dan menentukan tindakan yang akan mereka lakukan yang terkait dengan diri mereka sendiri, termasuk mengurangi efek hambatan pribadi dan sosial dalam melakukan tindakan. Hal ini memperkuat bahwa pemberdayaan masyarakat sangat di butuhkan kesadaran serta partisipasi dari masyarakat itu sendiri. Tanpa kesadaran dan partisipasi, maka akan sangat sulit mewujudkan masyarakat yang berdaya seperti harapaan dan tujuan yang sudah di tetapkan.

Menyangkut Desa, memang tidak dijelaskan secara eksplisit dalam UU. No. 32 Tahun 2004 Tentang Pemerintah Daerah, namun dalam perjalanannya terkait dengan Desa dijelaskan dalam Peraturan Pemerintah No. 72 Tahun 2005 Tentang Desa. Dalam penjelasan peraturan pemerintah tersebut dijelasakan pada Pasal 1 ayat (5) bahwa desa atau yang disebut dengan nama lain, selanjutnya disebut desa, adalah kesatuan masyarakat hukum yang memiliki batas-batas wilayah yang berwenang untuk mengatur dan mengurus kepentingan masyarakat hukum yang memiliki batas-batas wilayah yang berwenang untuk mengatur dan mengurus kepentingan masyarakat setempat berdasarkan asal-usul adat 
istiadat setempat yang diakui dan dihormati dalam sistem pemerintahan Negara Kesatuan Republik Indonesia.

Berdasarkan latar belakang pemikiran di atas, maka penulis mengambil 2 (dua) permasalahan, yakni: Pertama, Bagaimana Manajemen Pemberdayaan Masyarakat Dan Kedua, Bagaimana Pemberdayaan Masyarakat Desa Di Kabupaten Bengkalis?

Dalam tulisan ini lebih fokus melihat Bagaimana Manajemen Pemberdayaan Masyarakat Desa Di Kabupaten Bengkalis, mengingat pemberdayaan merupakan hal yang sangat pentig untuk di kembangkan karena menyangkut masa depan masyarakat kita dengan memperhatikan perencanaan, pengorganisasian, pelasanaan dan pengawasan, agar memperoleh manfaat sebesar-besar bagi kemakmuran rakyat secara berkelanjutan.

\section{METODE}

Metode penelitian ini menggunakan analisis kualitatif dengan klasifikasi data antara lain: berupa jurnal dan pemberitaan media secara online. Jenis penelitian studi literatur dengan mencari referensi teori yang relevan dengan kasus atau permasalahan yang ditemukan. Referensi teori yang diperoleh dengan jalan penelitian studi literatur dijadikan sebagai fondasi dasar dan alat utama untuk membahas manajemen pemberdayaan masyarakat desa di kabupaten Bengkalis.

\section{HASIL DAN PEMBAHASAN}

\section{Manajemen Pemberdayaan Masyarakat}

Manajemen dalam arti sederhana yaitu suatu pengelolaan terhadap sesuatu agar berguna bagi pemenuhan kebutuhan dan pencapaian tujuan. Para pakar manajemen pada umumnya menyebutkan bahwa manajemen adalah suatu pekerjaan yang melibatkan adanya ilmu, seni, fungsi dan tindakantindakan yang harus dilakukan untuk mencapai suatu tujuan tertentu (Ridin Sofwan: 2015).

Maka dari itu lanjut Ridin, manajemen dapat diartikan sebagai suatu kegiatan atau pekerjaan proses pengelolaan sumber daya dan dana secara berkesinambungan dan berkelanjutan untuk mencapai suatu tujuan atau produk sesuai yang direncanakan. Manajemen merupakan proses yang khas yang terdiri dari tindakan perencanaan, pengorganisasian, penggerakan dan pengendalian. Proses itu dilakukan untuk menentukan dan mencapai sasaran-sasaran yang telah ditentukan melalui pemanfaatan sumber daya manusia dan sumber daya lainnya.

Jadi dalam proses manajemen mencakup perencanaan, pengorganisasisan, penggerakan dan pengendalian. Semuanya saling memiliki keterkaitan, misalnya satu saja dari empat hal tersebut tidak terlaksana dengan baik maka akan berdampak kepada proses manajemen secara keseluruhan. Apalagi dalam proses pemberdayaan masyarakat, hal ini memiliki kompleksitas yang tinggi sesuai dinamika masalah di masyarakat, seperti pendidikan, kemiskinan dan kebudayaan. Oleh sebab itu dalam hal perencanaan segala aspek tersebut harus di pertimbangkan supaya dalam pengorganisasisan dan pelaksanaan terdapat keselarasan dengan memilih solusi yang paling tepat dengan masalah yang sudah di tetapkan, sehingga dalam pengendalian tidak menenemukan masalah baru yang dapat menghambat proses manajamen secara keseluruhan yang mengganggu tercapainya tujuan.

Kemudian Ridin menjelaskan Manajemen dapat didefinisikan sebagai seni dan ilmu sebagai alat untuk melakukan proses pengelolaan sumber daya dan dana melalui mekanisme fungsional dalam rangka melaksanakan berbagai kegiatan untuk mencapai tujuan yang telah ditetapkan lebih dahulu. Setiap pembicaraan manajemen dan aplikasinya akan melekat didalamnya dua hal yaitu organisasi dan 
administrasi. Hal itu berangkat dari suatu kondisi pragmatis bahwa setiap pelaksanaan manajemen berada dalam organisasi tertentu dengan sistem administrasi tertertu pula. Organisasi adalah wadah kerjasama antar dua orang atau lebih, sedangkan administrasi proses pencatatan kegiatan dari kelompok yang mengadakan kerjasama untuk meyelesaiakan tujuan bersama.

Artinya dalam kegiatan organisasi yang bersifat konstruktif/ membangun, penting adanya proses yang terncana, dengan adanya perencanaan di harapkan mampu meminimalisir hal-hal yang tidak di inginkan serta memaksimalkan segala potensi yang tersedia, dengan prinsip efektif dan efisien. Begitupun dalam hal menggerakkan potensi tersebut hingga proses pengendaliannya,semua harus terencana dengan baik.

Sedangkan pemberdayaan masyarakat pada hakekatnya adalah membuat masyarakat lebih berdaya, baik dari segi sumber daya manusia, keuangan, manajemen, akses, dan lain sebagainya. Banyak program pemberdayaan yang telah dilakukan. Penulis bersama-sama dengan peneliti yang lain telah melakukan banyak penelitian untuk mengembangkan program pemberdayaan, baik untuk mahasiswa, pemuda desa, kelompok masyarakat produktif, maupun masyarakat secara umum (Humam Santoso: 2012) .

Menurut Ajat Sudrajat Kurnia, istilah lembaga (institution) dan pengembangan kelembagaan (institutional development) atau pembinaan kelembagaan (institutional building) diartikan beragam menurut kacamata masing-masing. Namun secara umum, pengembangan kelembagaan didefinisikan sebagai proses untuk memperbaiki kemampuan lembaga guna mengefektifkan penggunaan sumber daya manusia dengan keuangan yang tersedia. Proses ini dapat secara internal digerakan oleh manajer sebuah lembaga atau dicampurtangani dan dipromosikan oleh pemerintah atau oleh badan-badan pembangunan.

Lanjut Ajat, tujuan utama pengembangan kelembagaan adalah mengefektifkan penggunaan sumberdaya di suatu negara misalnya, suatu tujuan utama bagi upaya pembangunan dan menjadi sangat mendesak dalam mengatasi krisis multidimensional dewasa ini, dikarenakan pengembangan kelembagaan merupakan proses menciptakan pola baru kegiatan dan perilaku yang bertahan dari waktu ke waktu karena didukung oleh norma, standar, dan nilai-nilai dari dalam masyarakat.

Jadi dalam pemberdayaan masyarakat di butuhkan lembaga pelaksana yang baik dan sehat, artinya segala proses kegiatan yang akan dilaksanakan dalam pemberdayaan sangat di tentukan oleh kualitas Sumber daya manusia maupun sumber daya lainnya yang ada di dalam organisasi pelaksana, sehingga di harapkan segala proses kegiatan dapat terncana dengan maksimal, dalam pengorganisasian dapat menciptakan konsep yang efektif dan efisien, dalam pelaksanaan dapat tepat sasaran dan dalam pengendalian dapat sesuai dengan yang sudah di rencanakan. Dengan kata lain dalam hal pemberdayaan Administrasi dann Organisasi tidak dapat di pisahkan.

Dalam Munawar Noor (2011) di jelaskan, Upaya pemerintah untuk meningkatkan keberpihakan pembangunan kepada kepentingan masyarakat nampaknya tidak akan lepas dari pemberdayaan masyarakat (empowerment) sebagai model pembangunan yang berdimensi rakyat. Berangkat dari kondisi itu pemerintah telah mengeluarkan berbagai kebijakan pemerintah:

1. Kebijakan Pemerintah tentang pemberdayaan masyarakat secara tegas tertuang dalam GBHN Tahun 1999 dan UU Nomor 32 Tahun 2004 tentang Pemerintahan Daerah. Dalam GBHN tahun 1999, khususnya didalam "Arah Kebijakan Pembangunan Daerah" antara lain dinyatakan "mengembangkan otonomi daerah secara luas, nyata dan bertanggung jawab dalam rangka pemberdayaan masyarakat, lembaga ekonomi, lembaga politik, lembaga hukum, lembaga keagamaan, lembaga adat dan lembaga swadaya masyarakat serta seluruh potensi masyarakat dalam wadah NKRI"

2. Dalam UU Nomor 22 Tahun 1999 tentang Pemerintahan Daerah, antara lain ditegaskan bahwa "halhal yang mendasar dalam undangundang ini adalah mendorong untuk memberdayakan masyarakat, menumbuhkembangkan prakarsa dan kreatifitas serta meningkatkan peran serta masyarakat" 
Mencermati kedua rumusan Kebijakan Pemerintah diatas dapat disimpulkan bahwa "kebijakan pemberdayaan masyarakat merupakan bagian yang tidak terpisahkan dari kebijakan otonomi daerah;

Dalam UU Nomor 25 Tahun 2000 tentnag Program Pembangunan Nasional (PROPENAS) Tahun 2000-2004 dan Program Pembangunan Daerah (BAPPEDA) dinyatakan bahwa tujuan pemberdayaan masyarakat adalah meningkatkan keberdayaan masyarakat melalui penguatan lembaga dan organisasi masyarakat setempat, penanggulangan kemiskinan dan perlindungan social masyarakat, peningkatan kswadayaan masyarakat luas guna membantu masyarakat untuk meningkatkan kehidupan ekonomi, social dan politik"

Dalam rangka mengemban tugas dalam bidang pemberdayaan masyarakat. Badan Pemberdayaan menetapkan visi, misi, kebijakan, strategi dan program pemberdayaan masyarakat sebagai berikut :

a. Visi Pemberdayaan Masyarakat adalah meningkatkan kemandirian masyarakat

b. Misi Pemberdayaan Masyarakat adalah mengembangkan kemampuan dan kemandirian dan secara bertahap masyarakat mempu membangun diri dan lingkungannya secara mandiri.

Jadi, dalam pemberdayaan dukungan kebijakan sangat di perlukan. Dalam hal kebijakan tentang pemberdayaan di Indonesia sudah baik, mulai dari Undang - undang yang lebih tinggi hingga aturanaturan yang ada di bawahnya. Namun yang menjadi point pentingnya adalah harus adanya linearitas kebijakan mulai dari Undang-undang hingga turunannya. Supaya dalam proses pelaksanaan tercipta harmonisasi dan keselarasan dengan karakter dan kebudayaan masyarakat yang menjadi sasaran pemberdayaan.

Selanjutnya Munawar menambahkan bahwa Kemandirian dalam konsep pemberdayaan masyarakat yang dimaksud adalah tingkat kemajuan yang harus dicapai sehingga masyarakat dapat membangun dan memelihara kelangsungan hidupnya berdasarkan kekuatannya sendiri secara berkelanjutan, artinya untuk membangun bangsa yang mandiri dibutukan perekonomian yang mapan.

Dalam Agus Purbathin Hadi (2009) menjelaskan Berbagai hasil penelitian yang mengkaji implementasi program program pengentasan kemiskinan dan pemberdayaan masyarakat tersebut, melaporkan berbagai keberhasilan dan juga ketidak-berhasilan program-program tersebut.Menurut Muktasam (2001) yang mengutip Chambers (1983), Harrison (1995), Burkey(1993), Esman and Uphoff (1984), atas dasar pengalaman para ahli tersebut dalam proses pembangunan pedesaan dan program pengentasan kemiskinan di negara-negara Asia dan Afrika, disimpulkan bahwa faktor-faktor penyebab kegagalan program pengentasan kemiskinan adalah: (1) Karena pendekatan 'target' dan'top-down'; (2)Pengabaian nilai-nilai lokal dan bias 'outsiders'; (3) Kurangnya partisipasi; (4)Pendekatan yang tidak holistik; dan (5) Ilusi investasi.

Menurut Adisasmita dalam Faizatul Karimah (2014) pemberdayaan masyarakat adalah upaya pemanfaatan dan pengelolaan sumber daya masyarakat perdesaan secara lebih efektif dan efisien, baik dari (a) aspek masukan atau input (sumberdaya manusia, dana, peralatan/sarana, data, rencana, dan teknologi; (b) dari aspek proses (pelaksanaan, monitoring, dan pengawasan); (c) dari aspek keluaran atau output (pencapaian sasaran, efektivitas, dan efisiensi). Tujuan pemberdayaan masyarakat menurut Sumaryadi (2005) pada dasarnya yaitu untuk membantu pengmbangan manusiawi yang otentik dan integral dari masyarakat yang lemah, miskin, marjinal dan kaum kecil serta untuk memberdayakan kelompok masyarakat tersebut secara sosio ekonomis sehingga mereka dapat lebih mandiri dan dapat memenuhi kebutuhan dasar hidup mereka namun sanggup berperan serta dalam pengembangan masyarakat.

Menurut Elliot dalam Faizatul Karimah (2014) ada tiga strategi pendekatan yang dipakai dalam proses pemberdayaan masyarakat, antara lain: (a) the walfare approach yaitu membantu memberikan bantuan kepada kelompokkelompok tertentu, misalnya mereka yang terkena musibah bencana alam dan pendekatan ini tidak dimaksudkan untuk memberdayakan rakyat dalam menghadapi proses politik dan kemiskinan rakyat, (b) the development approach, pendekatan ini memusatkan perhatian pada 
pembangunan peningkatan kemandirian, kemampuan, dan keswadayaan masyarakat, (c) the empowerment approach, pendekatan ini melihat kemiskinan sebagai akibat proses politik dan berusaha memberdayakan atau melatih rakyat untuk mengatasi ketidakberdayaannya.

Jadi, manajemen pemberdayaan masyarakat merupakan rangkaian proses dalam upaya memberikan keberdayaan kepada masyarakat miskin/lemah, supaya masyarakat tersebut menjadi mampu dalam mengelola kebutuhaannya sendiri, keluarga, dan lingkungannya secara mandiri. Proses ini mulai dari perencanaan (Planning), Pengorganisasian (Organizing), Pelaksanaan (Actuating) hingga Pengendalian (Controlling).

Pemberdayaan Masyarakat perlu di dukung linearitas kebijakan mulai dari Undang-undang hingga turunannya. Supaya tercipta keselarasan dengan karakter maupun kebudayaan masyarakat yang menjadi objek pemberdayaan, sehingga terdapat harmonisasi dalam penyelengggaraannya. Dengan kata lain, factor administrasi dan organisasi sangat mempengaruhi keberhasilan dalam pencapaian tujuan.

\section{Pemberdayaan Masyarakat Desa di Kabupaten Bengkalis}

Menurut Ketaren dalam Raja Muhamad Amin (2014) pemberdayaan adalah sebuah "proses menjadi", bukan sebuah "proses instan". Sebagai proses, pemberdayaan mempunyai tiga tahapan yaitu: Tahap pertama Penyadaran, pada tahap penyadaran ini, target yang hendak diberdayakan diberi pencerahan dalam bentuk pemberian penyadaran bahwa mereka mempunyai hak untuk mempunyai"sesuatu', prinsip dasarnya adalah membuat target mengerti bahwa mereka perlu (membangun"demand") diberdayakan, dan proses pemberdayaan itu dimulai dari dalam diri mereka (bukan dari orang luar). Setelah menyadari, tahap kedua adalah Pengkapasitasan, atau memampukan (enabling) untuk diberi daya atau kuasa, artinya memberikan kapasitas kepada individu atau kelompok manusia supaya mereka nantinya mampu menerima daya atau kekuasaan yang akan diberikan. Tahap ketiga adalah Pemberian Daya itu sendiri, pada tahap ini, kepada target diberikan daya, kekuasaan, otoritas, atau peluang, namun pemberian ini harus sesuai dengan kualitas kecakapan yang telah dimiliki mereka.

Ghofur (2014) menjelaskan, Program pemberdayaan yang dilakukan pemerintah bagi masyarakat suku Akit di pulau Rupat, umumnya tidak dibedakan dengan suku-suku lain yang tinggal di lingkungan tersebut. Pemerintah tidak memberi prioritas program pemberdayaan bagi suku Akit, padahal dalam realitas kehidupan mereka bahwa suku akit cenderung memiliki kekhasan dalam prilaku, budaya dan lebih banyak yang kurang mampu secara ekonomi. Suku akit oleh banyak pihak masih dikategorikan dalam kelompok masyarakat tradisional atau Komunitas Adat Tertinggal (KAT) seperti suku sakai, suku Akit, Talang mamak, suku laut, suku bonai, yang tersebar di proipinsi Riau.

Seharusnya pemerintah dalam pelaksanaan pemberdayaan masyarakat di kabupaten bengkalis menyesuaikan dengan karakter dan kebudayaan masyarakatnya, apalagi masyarakat desa yang dengan kategori Komunitas Adat Tertinggal (KAT) tersebut, mereka perlu sentuhan-sentuhan khusus yang semestinya di formulasikan ke dalam sebuah kebijakan, supaya menciptakan tujuan masyarakat yang berdaya dan mandiri dapat terlaksana secara maksimal.

Kemudian lanjut Ghofur, Bentuk-bentuk pemberdayaan yang dilakukan pemerintah maupun LSM di kecamatan Rupat Utara Kabupaten Bengkalis antara lain : Program INBUP-PPIP (Instruksi Bupati dan Program Penguatan Infrastruktur Pedesaan); ADD (Alokasi Dana Desa); UED-SP (Usaha Ekonomi Desa Simpan Pinjam); Rumah Layak Huni; penyediaan sarana dan prasarana kesehatan seperti Puskesmas; bidan dan ambulan (semuanya adalah progra pemerintah Kabupaten). Selanjutnya pemberdayaan dalam bentuk penyuluhan kepada masyarakat seperti penyuluhan Narkoba, AIDS dan HIV; penyuluhan kesehatan seperti imunisasi, pentingnya ASI; sanitasi lingkungan dan hidup bersih. Dari kalangan LSM ada pula program Indonesia Mengajar dikhususkan di Desa Titi Akar dan Hutan Ayu. 
Kemudian terdapat pula program PNPM Mandiri (Program Nasional Pemberdayaan Masyarakat); Pamsimas (keduanya program pemerintah pusat).

Iskandarsyah (2012) menyimpulkan hasil penelitiannya tentang Upaya Desa Api -Api Dalam Menjadi Desa Terbaik Se Kabupaten Bengkalis Tahun 2012, sebagai berikut :

1. Pemerintah Desa Api-Api telah menjalankan perannya dengan baik, yang dibuktikan dengan pencapaian menjadi Desa terbaik Se Kabupaten Bengkalis. hal ini dapat dilihat melalui, Pertama sebagai pelaksana program-program yang menghasilkan beberapa program-program pemberdayaan masyarakat yang telah ditetapkan, antara lain yaitu: Pengaktifan kelembagaan UPK (Unit Pengelola Keuangan),Peningkatan peran serta masyarakat dalam pembangunan, Peningkatan ekonomi produktif. Kedua, sebagai pelaksana kebijakan, Ketiga, sebagai pembina kehidupan masyarakat yang mencakup berbagai bidang seperti bidang ekonomi, bidang pelayanan kesehatan, bidang pendidikan. dan juga meningkatkan Pemerintah Desa, kelembagaan Desa. Melalui programprogram tersebut pemerintah Desa Api-Api bisa memberdayakan masyarakatnya dengan baik dalam menunjang kesejahteraandan kemandirian masyarakat desa.

2. Pemerintah Desa Api-Api mempunyai kerjasama yang baik antara pihakswasta dan masyarakat serta mempunyai anggaran dana yang baik dalam mendukung kelancaran pembangunan yang ada di DesaApi-Api. Desa Api -Api telah berusaha dengan baik untuk menjadi Desa yang terbaik, baik itu Pemerintah Desa, Kelembagaan, maupun masyarakat sudah menjalankan dan berusaha dengan baik untuk membangun dan mengembangkan potensi yang ada di Desa Api -Api. Pemerintah Desa dan masyarakat sudah melihatkan kerja sama yang baik untuk membangun Desa menjadi yang terbaik. Walaupun masih ada terdapat kendala-kendala atau hambatan dalam meningkatkan dan membangun Desa, semua bisa di atasi dengan baik oleh Desa Api -Api.

Dari pernyataan di atas kita melihat bahwa keberhasilan desa Api-api menjadi Desa terbaik SeKabupaten Bengkalis tidak terlepas dari kondisi organisasinya yang sehat, kerjasama yang baik dengan pihak swasta, memaksimalkan pelayanan kebutuhan masyarakat baik kesehatan, pendidikan dan sebagainya. Kemudian kebijakan pemerintah Desa yang menyelaraskan dengan karakter dan kebudayaan tradisional masyarakatnya, membangkitkan usaha ekonomi produktif masyarakatnya, hal-hal yang seperti diatas perlu sebaiknya di duplikasi oleh pemerintah kabupaten bengkalis dalam rangka pemberdayaan masyarakat desa-desa yang ada di kabupaten bengkalis.

Sementara Tarmi (2014) menjelaskan dalam Pelaksanaan Program Usaha Ekonomi Desa Simpan Pinjam (UED-SP) dalam Pemberdayaan Masyarakat di Desa Serai Wangi Kecamatan Pinggir Kabupaten Bengkalis. bahwa penyaluran dana bantuan UED-SP kepada Masyarakat tidak tepat sasaran, hal ini terjadi karena proses verifkasi dan penetapan anggota UED tidak sesuai dengan ketentuan Program UEDSP. Dalam pelaksanaan Program UED-SP terdapat anggota yang berhasil dan anggota yang gagal. Anggota yang berhasil pertama anggota UED-SP menggunakan dana untuk usaha dan disiplin dalam pembayarannya.

Kedua anggota menggunakam dana untuk konsumtif dan tepat waktu dalam pembayarannya dikarenakan anggota UED-SP memiliki keadaan ekonomi yang baik. Anggota UED-SP yang gagal karena kemunduran dalam usahanya dan anggota UED-SP memiliki etikad yang tidak baik sehingga anggota UED-SP mengalami penunggakan. Pengawasan terhadap pelaksanaan UED-SP tidak berjalan dengan efektif sehingga pengelolah tidak mengetahui kendala-kendala yang dihadapi oleh anggota UEDSP dan adanya penyalahgunaan dana. Selain itu sanksi terhadap pelaksanaan UED-SP tidak tegas menyebabkan program tidak bejalan dengan baik dan sukses.

Satu catatan penting dalam pemberdayaan masyarakat adalah bahwa bantuan dana yang di salurkan pemerintah dalam program apapun namanya harus di gunakan masyarakat sasaran untuk kegiatan yang produktif, sebab urgensinya adalah untuk memberdayakan masyarakat itu sendiri dan bukan untuk kepentingan sesaat. Oleh karena itulah pentingnya terklebih dahulu menanamkan kesadaran kepada 
masyarakat bahwa upaya pemerintah dalam memberdayakan masyarakat tersebut adalah kepentingan masyarakat sasaran itu sendiri untuk jangka panjang dan bukan untuk memenuhi kebutuhan konsuftif sesaat masyarakat sasaran yang pada akhirnya diharapkan dapat meningkatkan kesejahteraan masyarakat itu sendiri.

Hal ini di perkuat oleh pernyataan Labombang dalam Susi (2012) menjelaskan, di pedesaan terdapat berbagai masalah dan kebutuhan masyarakat, ada masalah pendidikan, kesehatan, perekonomian, lingkungan hidup dan lain-lain. Masyarakat berharap dapat lepas dari masalah-masalah tersebut. Di desa sebenarnya terdapat berbagai potensi sumber daya, ada potensi sumber daya alam atau sumber daya lingkungan dan sumber daya manusia. Pembangunan desa mencakup berbagai bidang kehidupan masyarakat. Pembangunan mencakup pribadi warganya dan lingkungannya, pembangunan untuk meningkatkan kesejahteraan warganya.

Kemudian Husinsyah dalam Susi (2012) menyatakan bahwa Pemberdayaan masyarakat dalam meningkatkan kemandirian dan kapasitasnya untuk berperan aktif dalam mewujudkan ketersediaan, distribusi dan konsumsi pangan dari waktu ke waktu dengan memanfaatkan kelembagaan sosial ekonomi yang telah ada dan dapat dikembangkan di tingkat pedesaan dengan fokus utama adalah rumah tangga pedesaan. Pengembangan desa mandiri pangan sebagai upaya mengintegrasikan dan mengimplementasikan berbagai model pemberdayaan ketahanan pangan masyarakat dalam suatu desa dengan melibatkan seluruh partisipasi masyarakat.

Dalam upaya pemberdayaan masyarakat desa di kabupaten bengkalis perlu menanamkan kesadaran kepada masyarakat yang menjadi sasaran pemberdayaan terhadap pentingnya pemberdayaan tersebut agar dalam pelaksanaan, masyarakat sasaran pemberdayaan dapat lebih partisipasif. Kemudian mempersiapkan organisasi dan kelembagaan yang sehat dalam hal ini pemerintah desa dan lembaga eksekutor program dengan memperhatikan sumber daya manusia dan sumber daya lainnya agar dalam pelaksanaan upaya pemberdayaan masyarakat desa di kabupaten bengkalis teralisasi dengan maksimal. Kerjasama dengan pihak swasta, termasuk memamksimalkan pelayanan kebutuhan dasar bagi masyarakat desa. Sehingga tujuan akhir yakni menciptakan masyarakat yang berdayaguna dan mandiri dapat tercapai.

\section{KESIMPULAN}

Pada bagian ini penulis menyimpulkan hasil pembahasan dan analisa manajemen pemberdayaan masyarakat di kabupaten bengkalis belum maksimal, hal ini terlihat dari lemahnya upaya pemerintah dalam upaya me linearisasi kebijakan hingga tingkat desa khususnya desa tradisional yang masih tertinggal, tentu butuh sentuhan-sentuhan khusus yang bisa di tuangkan ke dalam sebuah aturan/kebijakan. Upaya penyelarasan tersebut sangat di butuhkan supaya terciptanya harmonisasi dalam pelaksanaannya. Pemberdayaan Masyarakat perlu di dukung linearitas kebijakan mulai dari Undangundang hingga turunannya. Supaya tercipta keselarasan dengan karakter maupun kebudayaan masyarakat yang menjadi objek pemberdayaan, sehingga terdapat harmonisasi dalam penyelengggaraannya. Dengan kata lain, faktor administrasi dan organisasi sangat mempengaruhi keberhasilan dalam pencapaian tujuan

\section{SARAN}

Pemberdayaan masyarakat desa di kabupaten bengkalis juga belum terlaksana dengan maksimal. Hal ini terlihat dari lemahnya upaya pemerintah dalam menduplikasi strategi dari desa yang berhasil kepada desa-desa lainnya di kabupaten bengkalis. Dalam upaya pemberdayaan masyarakat desa di kabupaten bengkalis perlu menanamkan kesadaran kepada masyarakat yang menjadi sasaran 
pemberdayaan terhadap pentingnya pemberdayaan tersebut agar dalam pelaksanaan, masyarakat sasaran pemberdayaan dapat lebih partisipasif. Kemudian mempersiapkan organisasi dan kelembagaan yang sehat dalam hal ini pemerintah desa dan lembaga eksekutor program dengan memperhatikan sumber daya manusia dan sumber daya lainnya agar dalam pelaksanaan upaya pemberdayaan masyarakat desa di kabupaten bengkalis teralisasi dengan maksimal. Kerjasama dengan pihak swasta, termasuk memamksimalkan pelayanan kebutuhan dasar bagi masyarakat desa. Sehingga tujuan akhir yakni menciptakan masyarakat yang berdayaguna dan mandiri dapat tercapai.

\section{DAFTAR PUSTAKA}

[1]. Amin, Raja Muhammad, and Jumaidi Husin Irkami. (2014).Peran Pemerintahan Daerah dalam Pengembangan Desa Tertinggal di Kecamatan Rupat Kabupaten Bengkalis Tahun 2012. Jurnal Online Mahasiswa Fakultas Ilmu Sosial dan Ilmu Politik Universitas Riau

[2]. Fahrudin, Adi. (2011). Pemberdayaan, Partisipasi dan Penguatan Kapasitas Masyarakat."Bandung: Humaniora

[3]. Ghofur, Abd. (2014)Problematika Pembangunan Pulau Terluar Dan Pemberdayaan Masyarakat Di Kecamatan Rupat Utara Kabupaten Bengkalis. Toleransi.Hal 59-80.

[4]. Hadi, Agus Purbathin (2009) Tinjauan terhadap berbagai program pemberdayaan masyarakat di Indonesia." Yayasan Agribisnis/Pusat Pengembangan Masyarakat Agrikarya (PPMA).

[5]. Karimah, Faizatul. (2014) Pengelolaan Alokasi Dana Desa dalam Pemberdayaan Masyarakat (Studi pada Desa Deket Kulon, Kecamatan Deket, Kabupaten Lamongan). Jurnal Administrasi Publik Volume 2.No 4. 597-602.

[6]. Munir, Zainal Arifin. (2013) Revitalisasi Manajemen Wakaf Sebagai Penggerak Ekonomi Masyarakat." De Jure: Jurnal Hukum dan Syariah Volume 5.No.2

[7]. Noor, Munawar (2011) Pemberdayaan masyarakat. CIVIS 1.2/Juli

[8]. Payne, Ruby K. (2005) A framework for understanding poverty.

[9]. Sofwan, Ridin (2013) Penguatan Manajemen Pemberdayaan Fungsi Masjid Al-Fattah di Kelurahan Krapyak Semarang." Dimas: Jurnal Pemikiran Agama untuk Pemberdayaan Volume 13 No.2.Hal 315-334.

[10]. Susi, and Rita Yani Iyan. "Analisis prioritas penanggulangan kemiskinan menurut kabupaten/kota di Provinsi Riau." Jurnal Sosial Ekonomi Pembangunan 3.7 (2012): 71-87.

[11]. Syafar, Muhammad. (2015) Pemberdayaan Masyarakat dalam Pembangunan. Lembaran Masyarakat: Jurnal Pengembangan Masyarakat Islam Volume 1.No.2. Hal.125-154.

[12]. Syafrizal, Syafrizal, and Tarmi Tarmi. (2014) Pelaksanaan Program Usaha Ekonomi Desa Simpan Pinjam (UED-SP) dalam Pemberdayaan Masyarakat di Desa Serai Wangi Kecamatan Pinggir 
Kabupaten Bengkalis." Jurnal Online Mahasiswa Fakultas Ilmu Sosial dan Ilmu Politik Universitas Riau

[13]. Syahputra, Azwir, and Mayarni Mayarni (2016) Manajemen Pelaksanaan Program Penguatan Infrastruktur Perdesaan Di Desa Tasik Serai Barat Kecamatan Pinggir Kabupaten Bengkalis Tahun 2014." Jurnal Online Mahasiswa Fakultas Ilmu Sosial dan Ilmu Politik Universitas Riau Volume 3.No.2. Hal. 1-12. Lenggogeni,

[14]. Utomo, Humam Santoso. (2012) Pemberdayaan masyarakat melalui pendekatan sociopreneurship." Business conference $(B C)$. 